\title{
Analysis \& Design of Flyover by using Staad. Pro v8i
}

\author{
Narigiri Vijiya Bhargavi ${ }^{1}$ | J. Lakshmi Sudha ${ }^{2}$ | Dr. Dumpa Venkateswarlu ${ }^{3}$
}

${ }^{1}$ PG Scholar, Department of Civil Engineering, Godavari Institute of Engineering \& Technology (A), Rajahmundry ${ }^{2}$ Assistant Professor, Department of Civil Engineering, Godavari Institute of Engineering \& Technology (A), Rajahmundry ${ }^{3}$ Professor \& Head, Department of Civil Engineering, Godavari Institute of Engineering \& Technology (A), Rajahmundry

\section{To Cite this Article}

Narigiri Vijiya Bhargavi, J. Lakshmi Sudha and Dr. Dumpa Venkateswarlu, "Analysis \& Design of Flyover by using Staad. Pro v8i", International Journal for Modern Trends in Science and Technology, Vol. 07, Issue 03, March 2021, pp.: 272-279.

\section{Article Info}

Received on 15-February-2021, Revised on 10-March-2021, Accepted on 21-March-2021, Published on 23-March-2021.

\section{ABSTRACT}

As the population is growing, urbanization is caused which results in increasing of traffic with usage in more number of vehicles for different means of transport. As stated above the growth of population and the usage of vehicles for their different means will automatically result in increase in flow of vehicles which is called as traffic. To overcome the issue of traffic getting jammed (which means having obstacles for free moment or flow at a particular place), there are many different ways implemented to overcome it. When coming to Highways one of the efficient ways of overcoming it is construction of a flyover.Here in this project we are going to a design a flyover at Morampudi Junction located in Rajahmundry Andhra Pradesh along the National Highway 216A as a proposal in order to overcome the issue of traffic jam and also to reduce the rate of accidents occurring at the junction.

By considering all the data collected conducting different examinations I am going to design and analyze the flyover using software STAAD.Pro V8i to study Bending Moment, Shear Force, Nodal Displacement values by considering various types of loads considered are Dead Loads, Live Loads, Wind Loads, Vehicle Load which are taken from Indian Standard Codes IS - 456, IS - 800 \& IRC: 6 - 2016.

KEYWORDS: STAAD.PRO V8i, Shear force, Bending moment, IS - 456, IS - 800 \&IRC: 6-2016

\section{INTRODUCTION}

India is the country with the second largest road network across the world with 5.4 million $\mathrm{Km}$. This road network helps transportation more than $60 \%$ of all goods in the country and $85 \%$ of passenger traffic in India. Road transportation system has gradually increased over yearswith the improvement in connectivity between cities, towns and villages across thecountry. One of the major components of roadways if Flyover's.

\subsection{Introduction to Flyover}

Flyover may be referred as an overpass, a $h$ igh-level road bridge that crosses over a highway interchange or intersection.
It is a construction that is built over physical obstacles such as water bodies, valleys and roads which are provided for passage over the obstacle. Designs of flyover vary depending on the requirements and functionalities of the flyover, the nature of the soil where the flyover is constructed, the material that are used for construction and the funds available to build it.

\subsection{History Flyover}

The first flyover in the world was constructed and started in the year 1843 by the London and Croydon Railway department at Norwood Junction 
railway station to carry its atmospheric railway vehicles over the Brighton Main Line.

In India the first flyover was constructed and allowed to access from 14 April 1965 in Kemps Corner in Mumbai. The length of the bridge was 48' (foot) which was constructed in about seven months by Shirish Patel with the expenditure of 17.5 lacks.

A flyover consists of, number of spans with columns (piers), deck, and foundation etc. To construct a flyover all these elements are to be designed properly after analyzing. For large construction the process of designing and analyzing for the structure becomes complicated when done manually, it consumes lot of time and may lead to commencement of errors also, in order to meet the requirements of the proposed construction and complete the task without any problems, software's are used for efficient work.

The software's are used to perform analysis and designing with less effort and no errors with in short period of time, by which the designing of complex flyovers become easier using different software's.

Some of the software's which are generally used for analysis and designing of structures are ETABS, ROBOT STRUCTUREL ANALYSIS, STAAD.Pro V8i.

A flyover has three main elements. First the substructure, which is known as foundation, that which absorbs and transfers the load and weight of the bridge to the ground. It consists of components such as columns (also called piers) and abutments. An abutment is the connection between end of the bridge and the road carried by the earth; it provides support for the end sections of the flyover. Secondly, the superstructure of the flyover is the horizontal platform that spans the space between columns. Finally it comes to the deck of the bridge.

\subsection{Scope}

The investigation was performed on High Strength Grade ie., M60 grade concrete by using glass fibers and GGBS as mineral admixture The OPC was replaced by GGBS in the proportions of $0,10 \%$, $20 \%, 30 \%, 40 \%$ and glass fibers in the range of $0.5 \%, 1 \%, 1.5 \%, 2 \%$ with a SP dosage of $1.5 \%$ by weight of cement for mix along with $10 \%, 20 \%, 30 \%$ and $40 \%$ pumice stone as replacement to coarse aggregate.Mixes were prepared, cured and tested for identifying the mechanical strength characteristics of concrete after 28 days of conventional curing.

\section{Why flyover?}

As the usage of number of vehicles on the road is increasing and we don't have any area for extension on both sides, thus the only option left is to go with the third dimension and that is construction of a flyover.

\subsection{Components of Flyover}

The components of flyover is divided into two categories they are

1. Sub Structure.

2. Super Structure.

Based on the type of construction few parts get added and subtracted for better stability of the structure as-well to support the distribution process of loads applied on the structure.

\subsubsection{Sub Structure:}

This is the base supportive structure of the construction. Following are the parts which come under sub structure.
a) Foundation
b) Pier / Abutment
c) Bead Block
d) Bearing

\subsubsection{Super Structure:}

This is the structure which distributes the loads transferred by the vehicles moving on the construction. Following are the parts which come under sub structure.
a) Girder / Slab
b) Pavement
c) Railing / Parapet wall / Barrier

\subsection{Objectives:}

1.The main objective of this study is to know the reasons for variations in traffic flow at different times and occurrence of accidents at Morampudi junction and design a flyover as a solution for it. To provide free flow of traffic and enhances safe driving.

2. To study average density of traffic flow per day at Morampudi Junction on NH 216A.

3. To study and calculated Vehicle moving capacity at Morampudi Junction.

4. To know the effect of different load types i.e. Dead loads, Live loads, Wind loads, Vehicle loadwhichmay be taken considering codes as reference. 
5. To know the effect of design parameters on the structure i.e. bending moment, Shear force and Nodal Displacement.

6. To know the maximum load capacity of the flyover

\section{RELATED WORK}

Design of Flyover Bridge in TRICHY, in this paper the study deals with the problems occurring in high traffic area in Trichy. The analysis influences traffic behavior of both the structural components of highway and fly over bridge systems. Additionally, it is also demonstrated that beneficial effect on the superstructure response and sometimes produce detrimental effects on the system behavior and is dependent on the characteristics of the high volume of vehicle movement intensity. Here I consider the place to be from Trichy to Chennai Highway because there are more traffic problems especially in peak hours. It is an overpass and underpass together form a grade separation. Stack interchanges are made up of many over passes. For Pedestrians crossing over busy road without impacting traffic.

\section{Design of Flyover By Uing Staad Pro The} objective of this project is to do designing and analysis of flyover using Staad.Pro. The location of the flyover is at Velagapudi Ramakrishna Siddhartha Engineering College (KANURUVIJAYAWADA), which is facing major traffic problems. Completion of the flyover work is expected to ease traffic movement on the Bandar Road. The flyover is a part of the $3.3-\mathrm{km}$ new Pantakaluva Road that connects Autonagar's 100 ft. road and Tadigadapa- Enikepadu Road via Sanath Nagar, Kanuru Vijayawada Andhra Pradesh. The road follows the defunct irrigation stream (pantakaluva). The flyover is $204 \mathrm{~m}$ length with 12 spans, $17 \mathrm{~m}$ of each span. The diameter of the pier is about $1.6 \mathrm{~m}$ and the Beams are of I-section. The height of the columns is $4.2 \mathrm{~m}$.The Flyover has a road width of $8 \mathrm{~m}$ (2lanes), in which $0.5 \mathrm{~m}$ is of median. It also consists of footpath of 2 $\mathrm{m}$ width. In the post processing mode of the design we have worked on the structure and studied the bending moment and shear force values.

\section{Analysis And Design of Integral Flyover In} general Flyovers/Bridges are built with conventional method. In conventional method various elements like Bearings; Expansion joints need regular inspection and maintenance. The expansion bearings and joints, by virtue of their functions and sources of weakness in the bridge and there are many examples of distress in bridges, due to poor performance of these two elements primarily. This can be avoided by adopting Integral type of structures. Integral Bridges are the structures without joints. Integral bridges are characterized by monolithic connection between the deck and the substructure (piers and abutments). They span from one abutment, over intermediate support to the other abutment, without any joint in the deck. Integral bridges have been constructed all over the world including India. The work includes analysis and design of Integral structure by using STADD PRO software and manual analysis for simply supported structure.

Vikash Khatri et., at (2012) in this paper describesGrillage analysis is the most common method used inthe bridge analysis. In this method the deck isrepresented by an equivalent grillage of beams. Thefiner grillage mesh, provide more accurate results. Itwas found that the results obtained from grillageanalysis compared with experiments and morerigorous methods are accurate enough for designpurpose. The finite element method is a well-knowntool for the solution of complicated structuralengineering problems, as it is capable ofaccommodating many complexities in the solution. Inthis method, the actual continuum is replaced by anequivalent idealized structure composed of discreteelements, referred to as finite element, connectedtogether at a number of nodes.

Dr. Maher Qaqish et., al. (2008) this method is usually used for analysis of bridges based on the consideration of the bridge deck as an elastic continuum in the form of an orthogonally anisotropic plate. Using the stiffness method of structural analysis, it became possible to analyse the bridge deck structure as an assembly of elastic structural members connected together at discrete nodes. There are four distinct techniques which have been found useful by bridge engineers: grillage and space frame analysis, folded plate method, finite element method and finite strip method .The grillage analogy method involves a plane grillage of discrete interconnected beams.

M.A.Sobhan, A.F.M.Saiful Amin, the point of this paper is to upgrade and further invigorate the diverse controls of structural engineering and design that can enhance the execution and monetary return of a bridge over the long haul. To 
this end, the paper takes a note of current pattern of bridge engineering in Bangladesh and endeavors to give an advanced vision to improvement in the coming decades by keeping a match with the financial improvement status of the nation.

Narabodee Salatoom1, Pichai Taneerananon, suggested that to lessen traffic blockage at an at-grade crossing point close to a major city, one technique is construction a flyover bridge at the old junction in two bearings on one of the principle interstates. The flyover encourages the traffic stream in the bearings of the bridge, however the framework can't completely take care of the majority of the issues particularly on the optional road. Under the bridge, despite the fact that it mitigates the traffic blockage at the crossing point; the traffic flag still uses an indistinguishable control from the "before" circumstance, that is the settled time control plan. With the flyover bridge set up, it was found that around $30-35 \%$ of all traffic volumes occupied to the bridges, and time delay reduced by $30 \%$ over a similar period.

Kavitha.N, Jaya kumari.R, Jeeva.K, Bavithra.K, Kokila.K, project manages the Design of a grade separator in a convergence. The area is at four roads junction at SALEM town, which is confronting real traffic issues because of the construction. We have done a traffic survey and designed all the structural parts for this grade separator. The grade separator is of $640 \mathrm{~m}$ length with 21 ranges, $20 \mathrm{~m}$ for every traverse. It comprises of a deck slab, longitudinal braces, cross supports, deck pillar, wharf and establishment. Structural design of one traverse was made for all the above segments.

Anuj Dubey Tajammul Sayed, this paper underscores on the utilization of software's for scheduling purposes in Project Management. In India, dreary and tedious regular strategies are as yet utilized for project management as opposed to utilizing present day software instruments. The Hadapsar-Saswad Bridge in Pune is selected for construction booking as a contextual analysis. In this project the exercises were drilled down, amounts were evaluated, assets were assigned and henceforth a calendar was made. A few proposals were made on the site to beat the obstructions on the site without influencing the project's duration and furthermore not hampering excessively with the cost.

\section{EXPERIMENTAL STUDY METHODOLOGY}

The objective of the project is to design a flyover at Morampudi Junction located in Rajahmundry Andhra Pradesh along the National Highway 216A to overcome the issue of traffic jam and also to reduce the rate of accidents occurring at the junction.

\subsection{Problem statement}

By conducting different examinations like road survey and traffic analysis we came to a conclusion that the problem at Morampudi junction on $\mathrm{NH}$ $216 \mathrm{~A}$ is due to insufficiency of road space for the vehicles to pass through the junction at different instants of time in a day which is effecting the free flow of traffic, and improper movement of traffic also results in occurrence of accident in different instants of time

\subsection{Survey}

Survey is a method of research used for collection of data from different sources to execute the project efficiently.

In order to execute the project I have conducted survey to obtain the density of traffic flow and to determine the density of traffic flow in instants of time at Morampudi Junction on NH 216A.

Here by I have surveyed regarding density of vehicles at Morampudi Junction on NH 216A at different time intervals to obtain adequate results at that particular junction. I also have noticed that there are many different types of vehicles that are passing through Morampudi junction on NH 216A at different instants of time. There is variation in vehicles that pass through this junction, I here have noted down the density of traffic follow which passes through Morampudi Junction and came up with the conclusion of choosing the path along with the National Highway 216A for the construction of the flyover by taking necessary considerations. 


\subsection{Test Results and Discussion}

Table 1: Average density of traffic flow per day at Morampudi Junction on NH 216A
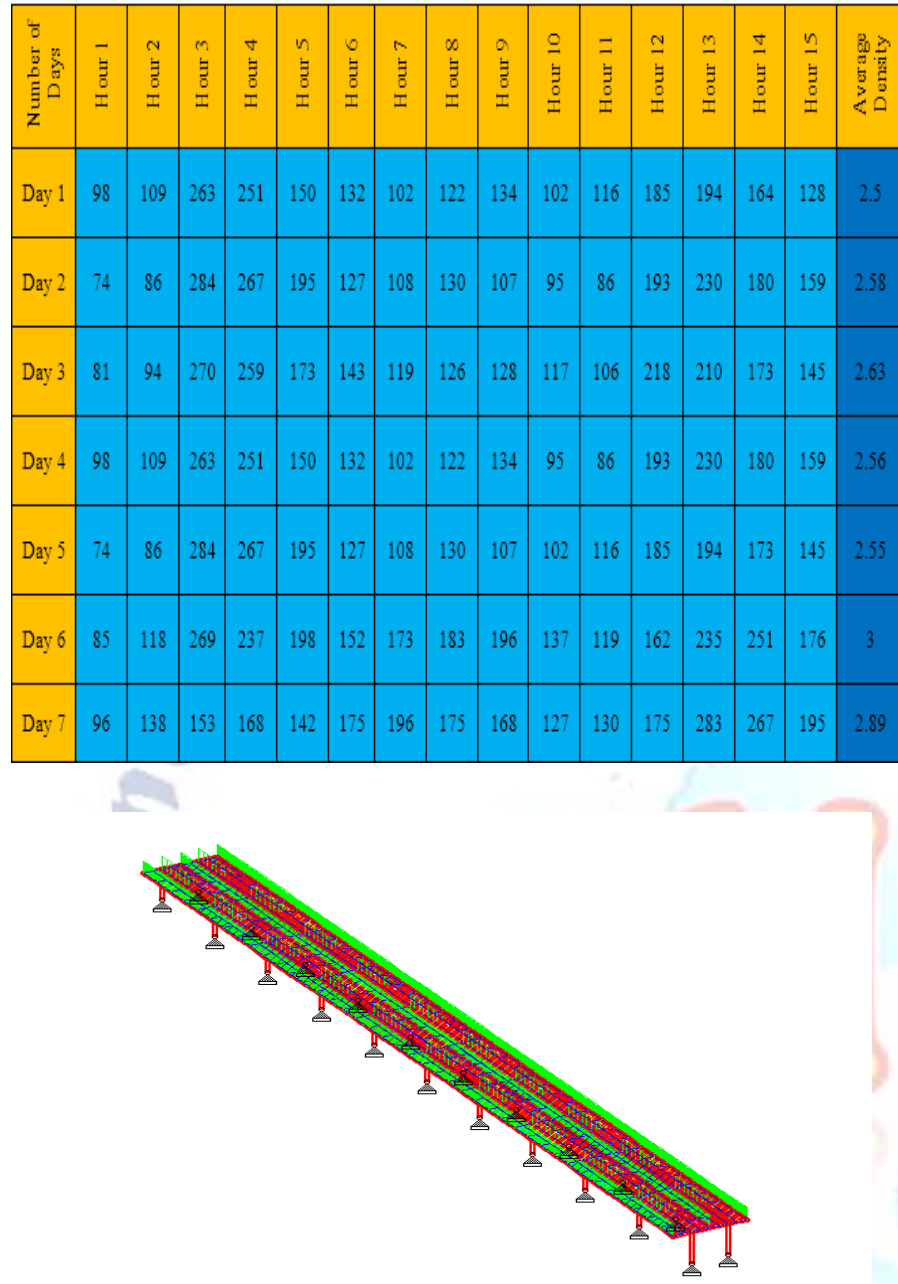

Fig.1Dead Load

\begin{tabular}{|c|c|c|}
\hline S. No & Vehicle Category & Recommended VDF \\
\hline 1 & Standard Buses & 4.065 \\
\hline 2 & Mini Bus & 0.923 \\
\hline 3 & Two Axle Trucks & 4.065 \\
\hline 4 & Three Axle Trucks & 6.202 \\
\hline 5 & 4 - 6 Axle Trucks & 12.1 \\
\hline 6 & 7 or More Axle Trucks & 12.1 \\
\hline 7 & LCV (Light Commercial Vehicles) & 0.923 \\
\hline
\end{tabular}

Fig.2 Vehicle Damaging Factor
1II [4 717 Fig.3 Live Load

\begin{tabular}{|c|c|}
\hline Zone & Basic wind speed $(\mathrm{m} / \mathrm{sec})$ \\
\hline I & 33 \\
\hline II & 39 \\
\hline III & 44 \\
\hline IV & 47 \\
\hline V & 50 \\
\hline VI & 55 \\
\hline
\end{tabular}

Table.2 Zone wise basic wind speed in $\mathrm{m} / \mathrm{s}$

\begin{tabular}{|c|c|c|c|c|c|c|c|c|c|c|}
\hline \multirow[b]{3}{*}{ IMD station } & \multirow{2}{*}{$\begin{array}{l}\text { Total no. } \\
\text { of records }\end{array}$} & \multirow{2}{*}{$\begin{array}{l}\text { Available number } \\
\text { of years of } \\
\text { maximum } \\
\text { gust wind speed }\end{array}$} & \multicolumn{4}{|c|}{ Raw hourly gust statistics (Figure I) } & \multicolumn{4}{|c|}{ Up-cross peaks statistics (Figure 2) } \\
\hline & & & $\begin{array}{c}W_{\max } \\
\text { kmph }\end{array}$ & $\begin{array}{c}\text { Wenean } \\
\text { kmph }\end{array}$ & $\begin{array}{l}\text { Weskd } \\
\text { kmph }\end{array}$ & $\begin{array}{c}\text { Extreme } \\
\text { kmph }\end{array}$ & $\begin{array}{l}\text { Number } \\
\text { of peaks }\end{array}$ & $\begin{array}{c}\text { EP-mean } \\
\text { kmph }\end{array}$ & $\begin{array}{c}\text { EP-Sld } \\
\text { kmph }\end{array}$ & $\begin{array}{c}\text { ExtremeP } \\
\text { kmph }\end{array}$ \\
\hline & Count & $A$ & $B$ & $D_{n}$ & $D_{\text {st }}$ & $D_{\text {paik }}$ & Count & $E_{m}$ & $E_{* \mathrm{~d}}$ & $E_{\text {pat }}$ \\
\hline HASHIMARA & 2882 & 9 & 125 & 31 & 13 & 72 & 1386 & 24 & 15 & 68 \\
\hline MADRAS_HARBOUR & 6177 & 20 & 150 & 42 & 13 & 81 & 3045 & 35 & 17 & 85 \\
\hline TUTICORIN HP & 5275 & 15 & 140 & 51 & 14 & 94 & 2833 & 47 & 16 & 95 \\
\hline MANGALORE_HP & 1451 & 4 & 91 & 38 & 13 & 76 & 761 & 35 & 12 & 70 \\
\hline AMRITSAR - & 11099 & 32 & 190 & 37 & 19 & 94 & 5921 & 31 & 17 & 82 \\
\hline PALAM_A & 12626 & 35 & 199 & 39 & 15 & 85 & 6792 & 34 & 14 & 78 \\
\hline NEWDEL̄HI_SAFRJG & 12310 & 34 & 152 & 35 & 15 & 79 & 6457 & 30 & 14 & 71 \\
\hline CHABUA_Ā & 395 & 2 & 72 & 28 & 12 & 65 & 155 & 16 & 15 & 60 \\
\hline JAIPUR_SANANGANER & 11697 & 38 & 181 & 32 & 15 & 76 & 6148 & 27 & 14 & 70 \\
\hline LUCKNOW_AMAUSI & 7160 & 18 & 170 & 39 & 16 & 87 & 3637 & 33 & 16 & 81 \\
\hline BAGHOGRÄA & 2921 & 9 & 102 & 31 & 13 & 70 & 1448 & 24 & 15 & 68 \\
\hline ALLAHABAD BAMHRAULI & 1863 & 3 & 131 & 31 & 14 & 73 & 452 & 27 & 13 & 65 \\
\hline VARANASI_BABATPUR & 539 & 2 & 67 & 25 & 9 & 52 & 277 & 21 & 9 & 49 \\
\hline GAYA & 2207 & 7 & 120 & 34 & 16 & 83 & 1163 & 29 & 16 & 76 \\
\hline NEW_KANDLA & 7407 & 22 & 132 & 47 & 15 & 91 & 3989 & 43 & 15 & 88 \\
\hline AHMEDABAD & 9652 & 29 & 150 & 35 & 11 & 69 & 5019 & 31 & 12 & 68 \\
\hline BHOPAL_BAIRAGARH & 7784 & 22 & 125 & 42 & 14 & 83 & 4158 & 38 & 13 & 78 \\
\hline JAMNAḠAR_A & 4328 & 15 & 182 & 44 & 13 & 83 & 2209 & 38 & 16 & 86 \\
\hline BARODA & 7564 & 22 & 155 & 35 & 13 & 72 & 4052 & 31 & 13 & 70 \\
\hline INDORE & 6959 & 21 & 136 & 52 & 13 & 91 & 3704 & 47 & 15 & 92 \\
\hline JAMSHEDPUR_PB & 1395 & 4 & 118 & 34 & 18 & 89 & 730 & 29 & 16 & 78 \\
\hline JAMSHEDPUR & 1284 & 4 & 122 & 36 & 17 & 87 & 646 & 30 & 17 & 79 \\
\hline KALAIKUNDA_A & 2536 & 8 & 142 & 40 & 17 & 91 & 1283 & 33 & 18 & 87 \\
\hline CALCUTTA & 6074 & 18 & 143 & 40 & 16 & 88 & 3133 & 35 & 16 & 82 \\
\hline CALCUTTA_DUMDUM & 9966 & 29 & 200 & 34 & 17 & 83 & 5272 & 29 & 15 & 75 \\
\hline NAGPUR_ONEGAON & 9348 & 26 & 132 & 36 & 15 & 81 & 5013 & 32 & 14 & 74 \\
\hline RAIPUR $^{-}$ & 6442 & 22 & 112 & 28 & 13 & 67 & 3443 & 24 & 12 & 61 \\
\hline JHARSUGUDA & 1216 & 4 & 120 & 37 & 17 & 89 & 657 & 32 & 16 & 80 \\
\hline SAGAR_ISLAND & 6603 & 19 & 163 & 31 & 16 & 79 & 3458 & 26 & 15 & 73 \\
\hline VERAVĀL & 4427 & 16 & 150 & 40 & 12 & $n$ & 2341 & 35 & 14 & $n 7$ \\
\hline BOMBAY_SANTACRUZ & 13616 & 38 & 200 & 36 & 10 & 67 & 7262 & 33 & 10 & 64 \\
\hline AURANGABAD_CHIKATHA & A 394 & 2 & 52 & 32 & 8 & 56 & 117 & 15 & 16 & 64 \\
\hline JAGDALPUR & 3438 & ii & 125 & 33 & 13 & 73 & 1764 & 28 & 13 & 67 \\
\hline GOPALPUR & 3764 & i1 & 140 & 43 & 15 & 89 & 1999 & 39 & 15 & 83 \\
\hline BOMBAY & 12530 & 36 & 103 & 37 & 12 & 74 & 6649 & 34 & 13 & 72 \\
\hline PUNE & 13410 & 38 & 165 & 34 & 10 & 66 & 7116 & 31 & 11 & 64 \\
\hline PUNE_ALOHAGAON & 4253 & 14 & 130 & 46 & 13 & 85 & 2210 & 41 & 16 & 88 \\
\hline BIDAR_A & 3321 & 10 & 137 & 46 & 15 & 90 & 1557 & 36 & 20 & 96 \\
\hline HYDERABD_A & 9291 & 28 & 140 & 37 & 13 & 77 & 4845 & 34 & 13 & 73 \\
\hline HAKIMPET $\bar{A}$ & 4161 & 12 & 114 & 44 & 14 & 87 & 2146 & 39 & 15 & 83 \\
\hline VISHAKHAPATNAM_A & 6211 & 18 & 196 & 43 & 14 & 85 & 3198 & 39 & 14 & 79 \\
\hline VIZG_RSRW & 3754 & 13 & 140 & 34 & 13 & 72 & 2079 & 31 & 12 & 68 \\
\hline MORMUGAO & 12549 & 37 & 190 & 35 & 14 & 77 & 6542 & 31 & 14 & 74 \\
\hline YEL_AHANKA_A & 1332 & 4 & 124 & 43 & 18 & 96 & 674 & 36 & 20 & 95 \\
\hline MADRAS & 761 & 3 & 98 & 32 & 10 & 61 & 396 & 30 & 9 & 57 \\
\hline MADRAS_MINAMBAKKAM & 14098 & 41 & 160 & 38 & 13 & $n$ & 7374 & 33 & 14 & 75 \\
\hline MANGALORE_HP_PANBUR & 9875 & 28 & 110 & 31 & 12 & 67 & 4818 & 25 & 14 & 66 \\
\hline BANGALORE & 11319 & 32 & 106 & 38 & 10 & 69 & 5965 & 34 & 12 & 70 \\
\hline NAMGALORE_A & 10969 & 32 & 125 & 41 & 11 & 75 & 5738 & 37 & 12 & 74 \\
\hline TAMBARAM_A & 4844 & 5 & 104 & 45 & 12 & 79 & 1677 & 24 & 23 & 92 \\
\hline PORT_BLAIR & 10253 & 29 & 170 & 40 & 17 & 89 & 5575 & 36 & 16 & 84 \\
\hline KODAIKANAL & 13183 & 37 & 190 & 40 & 12 & 76 & 6453 & 33 & 16 & 81 \\
\hline TIRUCHIRAPALLI_A & 13261 & 37 & 167 & 50 & 15 & 95 & 6928 & 46 & 15 & 92 \\
\hline COCHIN_NAS & 9418 & 29 & 180 & 36 & 12 & 72 & 4929 & 32 & 13 & 70 \\
\hline TRIVANDRUM_TIRUAN & 9908 & 29 & 108 & 29 & 11 & 61 & 5655 & 27 & 11 & 60 \\
\hline TRIVANDRUM_A & 7976 & 25 & 92 & 30 & 11 & 64 & 4387 & 27 & 12 & 63 \\
\hline TUTICORIN & 7761 & 23 & 146 & 49 & 13 & 87 & 4111 & 45 & 13 & 84 \\
\hline OZAR & 2825 & 7 & 102 & 42 & 15 & 86 & 1494 & 37 & 16 & 87 \\
\hline
\end{tabular}


Fig. 4 Table of wind pressure in different cities $\&$ towns

Based on the values given in the table 3.3, vales of zone VISHAKAPATNAM_A are being considered.

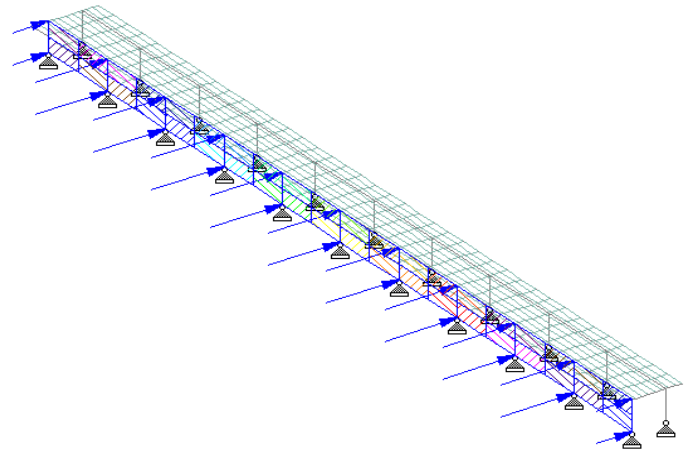

Fig. 5 Wind Load

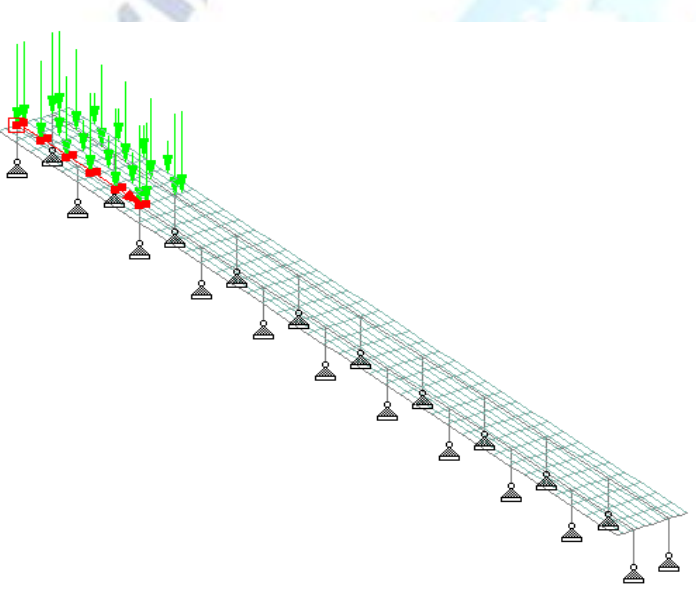

Fig.6 Axial Load

Vehicle impact loads are calculated using IS 875(Part-5)-1987.

Axial loads are calculated using IS 456-2000.

\section{Design Process:}

Size of column $=600 \times 600 \mathrm{~cm}$

Axial load $=750 \mathrm{KN}$

Safe Bearing Capacity $(\mathrm{SBC})=200 \mathrm{KN} / \mathrm{m}^{2}$

$\mathrm{f}_{\mathrm{ck}}=20 \mathrm{~N} / \mathrm{mm}^{2}$

$\mathrm{f}_{\mathrm{y}}=415 \mathrm{~N} / \mathrm{mm}^{2}$

\section{a. Size of floating:}

Load from the column $(\mathrm{P})=750 \mathrm{KN}$

Self-weight of footing $=10 \%$ of column weight

$=750 / 10$

$=75 \mathrm{KN}$

Total load $=750+75$

$$
=825 \mathrm{KN}
$$

\section{Area of footing}

$\mathrm{A}=\frac{\text { Total Load }}{\mathrm{SBC}}$

$=\frac{825}{200}$

$=4.125 \mathrm{~m}^{2}$

As footing is square

$$
\mathrm{A}=\mathrm{B}^{2}
$$

$$
\begin{aligned}
\mathrm{B} & =\sqrt{ } \mathrm{A} \\
& =\sqrt{ } 4.125 \\
\mathrm{~B} & =2.1 \mathrm{~m}
\end{aligned}
$$

\section{b. Upward soil pressure:}

Factored load $=1.5 \times 750$

$$
=1125 \mathrm{KN}
$$

Soil pressure at ultimate load $\left(\mathrm{qu}_{\mathrm{u}}\right)=\frac{\mathrm{Pu}}{\text { area of footing }}$

$$
\begin{aligned}
& =\frac{1125}{2.1 \times 2.1} \\
& =255 \mathrm{KN} / \mathrm{m}^{2} \\
& \quad \mathrm{q}_{\mathrm{u}}=0.255 \mathrm{~N} / \mathrm{m}^{2}
\end{aligned}
$$

\section{c. Depth of footing}

$\mathrm{M}_{\mathrm{u}}=\mathrm{M}_{\mathrm{u}} \lim$

$\mathrm{M}_{\mathrm{u}}=0.138 \mathrm{f}_{\mathrm{ck}} \mathrm{Bd}^{2}$

$\mathrm{M}_{\mathrm{u}}=\mathrm{q}_{\mathrm{u}} \frac{\mathrm{B}(\mathrm{B}-\mathrm{b}) 2}{8}$

$$
=0.255 \times \frac{2100(2100-300) 2}{8}
$$

$\mathrm{M}_{\mathrm{u}}=216.88 \times 10^{6} \mathrm{~N}-\mathrm{mm}$

$\mathrm{d}=\sqrt{\frac{\mathrm{Mu}}{0.138 \times \mathrm{FckxB}}}$

$d=\sqrt{ } \frac{216.88 \times 106}{0.138 \times 20 \times 2100}$

$\mathrm{d}=193.43 \mathrm{~mm}$

Depth required to resist shear in footing is much higher than required for B.M

Let us assume the effective depth is twice the depth required for B.M

$\mathrm{d}=193.43 \times 2$

$\mathrm{d}=386.86 \mathrm{~mm} \approx 400 \mathrm{~mm}$

$\mathrm{D}=\mathrm{d}+50$

$\mathrm{D}=400+50$

$\mathrm{D}=450 \mathrm{~mm}$

$\mathrm{B}=2100 \mathrm{~mm}$

\section{d. Reinforcement (Area of steel)}

$\mathrm{M}_{\mathrm{u}}=0.87 \mathrm{f}_{\mathrm{y}} \times \mathrm{A}_{\mathrm{st}} \times \mathrm{d}\left[1-\frac{\mathrm{fy} \times \mathrm{Ast}}{\mathrm{Fck} \times \mathrm{Bd}}\right]$

$216.88 \times 10^{6}=0.87 \times 415 \times A_{\text {st }} \times 400 \times[1-$

$\left.\frac{415 \times \text { Ast }}{20 \times 2100 \times 400}\right]$

$\mathrm{A}_{\mathrm{st}}=1561.86 \mathrm{~m}^{2} \approx 1562 \mathrm{~m}^{2}$ 


\section{Spacing}

$$
\mathrm{S}=\frac{\text { ast }}{\text { Ast }} \times 2100
$$

Assuming $\emptyset$ of bar as $12 \mathrm{~mm}$

$$
=\frac{\frac{\pi(12) 2}{4}}{151.86} \times 2100
$$

$\mathrm{S}=152.06 \approx 152 \mathrm{~mm}$

Providing $12 \mathrm{~mm} \emptyset$ bars at $152 \mathrm{~mm} \mathrm{C} / \mathrm{C}$

\section{e. Check for shear: $\left(\tau_{\mathrm{c}}>\tau_{\mathrm{v}}\right)$}

The critical section for one-way shear is at a distance 'd' from the face of column [Take value of $\boldsymbol{\tau}_{\mathrm{c}}$ from IS 456-2000 from table 19 P. No 73]

$$
\begin{aligned}
\boldsymbol{\tau}_{\mathrm{v}} & =\frac{\mathrm{Vu}}{\mathrm{Bd}} \\
\mathrm{V}_{\mathrm{u}} & =\mathrm{q}_{\mathrm{u}} \times \mathrm{Bx}\left[\frac{(\mathrm{B}-\mathrm{b})}{2}\right]-\mathrm{d} \\
& =0.255 \times 2100 \times\left[\frac{2100-600}{2}\right]-400 \\
\mathrm{~V}_{\mathrm{u}} & =401.225 \times 10^{3} \mathrm{~N} \\
\boldsymbol{\tau}_{\mathrm{v}} & =\frac{267.75 \times 10(3)}{2100 \times 400}=0.318 \mathrm{~N} / \mathrm{mm}^{2} \\
\boldsymbol{\tau}_{\mathrm{c}} & =\frac{\text { Ast }}{\mathrm{Bd}} \times 100 \\
& =\frac{1562}{2100 \times 400} \times 100 \\
\mathrm{P}_{\mathrm{t}} & =0.2 \%
\end{aligned}
$$

From table no $19 \boldsymbol{\tau}_{\mathrm{c}}$ based on $\mathrm{P}_{\mathrm{t}}$ and grade of concrete $\mathrm{M}_{20}$ is taken as $0.32 \mathrm{~N} / \mathrm{mm}^{2}$

$$
\therefore \boldsymbol{\tau}_{\mathrm{c}}>\boldsymbol{\tau}_{\mathrm{v}} \text { (Hence safe) }
$$

\section{Check for two ways shear:}

The critical section is at distance of $d / 2$ from face of column

Perimeter of the section $(\mathrm{p})=4(\mathrm{~b}+\mathrm{d})$

$\mathrm{P}=4(600+400)$

$\mathrm{P}=4000 \mathrm{~mm}$

Area of cross section $(\mathrm{A})=\mathrm{p} \times \mathrm{d}$

$$
\begin{aligned}
= & 4000 \times 400 \\
= & 16 \times 10^{5} \mathrm{~mm}^{2}
\end{aligned}
$$

$\mathrm{V}_{\mathrm{u} 2}=\mathrm{q}_{\mathrm{u}} \mathrm{x}$ (Area of shaded portion)

$$
=0.255 \times[(2100 \times 2100)-(700 \times 700)]
$$

$\mathrm{V}_{\mathrm{u} 2}=999.86 \times 10^{3} \mathrm{~N}$

Two-way shear $=\frac{\mathrm{Vu} 2}{\mathrm{~A}}$

$$
=\frac{999.86 \times 10(3)}{1.12 \times 10(6)}
$$

$\boldsymbol{\tau}_{\mathrm{v} 2}=0.89 \mathrm{~N} / \mathrm{mm}^{2}$

Permissible punching stress $\left(\boldsymbol{\tau}_{\mathrm{p}}\right)$

$$
\begin{aligned}
& \boldsymbol{\tau}_{\mathrm{p}}=0.25 \sqrt{ } \mathrm{f}_{\mathrm{ck}} \\
&=0.25 \sqrt{ } 20 \\
&=1.12 \mathrm{~N} / \mathrm{mm}^{2} \\
& \therefore \boldsymbol{\tau}_{\mathrm{p}}>\boldsymbol{\tau}_{\mathrm{v} 2} \text { Hence safe }
\end{aligned}
$$

\begin{tabular}{|c|c|c|c|c|}
\hline Beam & $\begin{array}{l}\text { Negative/Positive } \\
\text { Bending Moment }\end{array}$ & $\mathrm{Mx}(\mathrm{KNm})$ & $\mathrm{My}(\mathrm{KNm})$ & $\mathrm{Mz}(\mathrm{KNm})$ \\
\hline 17 & Max Fx & 0 & 0 & 0 \\
\hline 60 & $\operatorname{Min} \mathrm{Fx}$ & 0 & -0.413 & 456.523 \\
\hline 15 & $\mathrm{Max} F \mathrm{Fy}$ & -57.007 & -0.604 & 672.141 \\
\hline 177 & $\operatorname{Min} F y$ & 56.611 & -0.245 & 597.339 \\
\hline 116 & $\mathrm{Max} F z$ & 0 & -1161.445 & -180.97 \\
\hline 6 & $\operatorname{Min} \mathrm{Fz}$ & 0 & 1161.445 & -180.97 \\
\hline 4 & Max Mx & 295.598 & 29.029 & 367.813 \\
\hline 114 & $\operatorname{Min} \mathrm{Mx}$ & -295.598 & -29.029 & 367.813 \\
\hline 6 & Max My & 0 & 1161.445 & -180.97 \\
\hline 116 & Min My & 0 & -1161.445 & -180.97 \\
\hline 107 & Max Mz & -0.756 & 0.052 & 1122.79 \\
\hline 17 & Min MZ & 0 & -132.987 & -366.294 \\
\hline
\end{tabular}

In two-way shear, form claws 26.2.11 P. No 43 based on the grade of Concrete is 1.2

From HYSD or deformed bars the value is increased by $60 \%$
Check for development of length $\left(L_{d}\right)$ :

$\mathrm{L}_{\mathrm{d}}=\frac{0.87 \times \mathrm{fy} \times \emptyset}{4 \times \mathrm{td}}$

$\emptyset$ is $12 \mathrm{~mm}$ of bar

$$
=\frac{0.87 \times 415 \times 12}{4 \times \operatorname{td} \times 1.2 \times 1.6}
$$

Length available beyond the column is

$$
\begin{aligned}
\frac{2100-300}{2} & =900 \\
\therefore 900 & >564
\end{aligned}
$$

Table for maximum Shear Force values in $x, y, z$ directions

\begin{tabular}{|c|c|c|c|c|}
\hline Beam & $\begin{array}{c}\text { Negative/Positive Shear } \\
\text { Force }\end{array}$ & $\mathrm{Fx}(\mathrm{KN})$ & $\mathrm{Fy}(\mathrm{KN})$ & $\mathrm{Fz}(\mathrm{KN})$ \\
\hline 17 & $\operatorname{Max} \mathrm{Fx}$ & 2918.121 & -120.175 & 43.631 \\
\hline 60 & $\operatorname{Min} \mathrm{Fx}$ & -299.021 & 149.778 & 0.135 \\
\hline 15 & $\mathrm{Max} \mathrm{Fy}$ & 74.49 & 1450.116 & 2.675 \\
\hline 177 & $\operatorname{Min} \mathrm{Fy}$ & 53.098 & -1303.46 & -0.637 \\
\hline 116 & $\operatorname{Max} \mathrm{Fz}$ & 1310.072 & -59.373 & 381.051 \\
\hline 6 & $\operatorname{Min} \mathrm{Fz}$ & 1310.072 & -59.373 & -381.051 \\
\hline 4 & $\operatorname{Max} \mathrm{Mx}$ & 92.593 & 542.852 & -149.852 \\
\hline 114 & $\operatorname{Min} \mathrm{Mx}$ & 92.593 & 542.851 & 149.852 \\
\hline 6 & $\operatorname{Max} \mathrm{My}$ & 1310.072 & -59.373 & -381.051 \\
\hline 116 & $\operatorname{Min} \mathrm{My}$ & 1310.072 & -59.373 & 381.051 \\
\hline 107 & $\operatorname{Max} \mathrm{Mz}$ & 58.226 & 810.872 & -0.011 \\
\hline 17 & $\operatorname{Min} \mathrm{Mz}$ & 2897.112 & -120.175 & 43.631 \\
\hline
\end{tabular}

Table for maximum Bending Moment values in $\underline{x, y, z \text { directions }}$ 
Table for summary of Node Displacements

\begin{tabular}{|c|c|c|c|c|c|c|c|c|}
\hline \multirow{2}{*}{$\begin{array}{l}\text { Max \& Mim } \\
\text { Displacements } \\
\text { Chart Area }\end{array}$} & \multirow{2}{*}{ Node } & \multirow{2}{*}{\begin{tabular}{|l} 
Horizontal \\
$\mathrm{X}(\mathrm{mm})$
\end{tabular}} & \multirow{2}{*}{$\begin{array}{l}\text { Vertical } \\
\mathrm{Y}(\mathrm{mm})\end{array}$} & \multirow{2}{*}{$\begin{array}{l}\text { Horizontal } \\
\mathrm{Z}(\mathrm{mm})\end{array}$} & \multirow{2}{*}{$\begin{array}{l}\text { Resultant } \\
\text { Resultant }\end{array}$} & \multicolumn{3}{|c|}{ Rotational } \\
\hline & & & & & & $\mathrm{rX}(\mathrm{rad})$ & $\mathrm{rY}(\mathrm{rad})$ & $\mathrm{rZ}(\mathrm{rad})$ \\
\hline $\operatorname{Max} \mathrm{X}$ & 3 & 29.262 & 0.144 & 0.024 & 29.262 & 0 & 0 & -0.006 \\
\hline $\operatorname{Min} X$ & 443 & -0.976 & 0.005 & -0.872 & 1.309 & 0 & 0 & 0 \\
\hline $\operatorname{Max} Y$ & 107 & 4.121 & 7.854 & -0.068 & 8.87 & 0.001 & 0 & 0 \\
\hline $\operatorname{Min} Y$ & 5 & 7.164 & -70.178 & 0.56 & 70.545 & -0.003 & 0 & -0.017 \\
\hline $\operatorname{Max} Z$ & 71 & 0.966 & 0.227 & 2.883 & 3.049 & 0 & 0 & 0 \\
\hline $\operatorname{Min} Z$ & 5 & 7.312 & -11.912 & -3.211 & 14.341 & -0.009 & 0 & -0.008 \\
\hline Max IX & 75 & 6.979 & -14.295 & 0.855 & 15.931 & 0.021 & 0 & 0.013 \\
\hline Min $\mathrm{X} X$ & 493 & 6.979 & -14.295 & -0.855 & 15.931 & -0.021 & 0 & 0.013 \\
\hline Max ry & 90 & 9.268 & -0.16 & -1.518 & 9.393 & -0.008 & 0 & -0.001 \\
\hline $\operatorname{Min} r Y$ & 12 & 9.268 & -0.16 & 1.513 & 9.392 & 0.008 & 0 & -0.001 \\
\hline Max $\mathrm{Z} Z$ & 8 & 7.272 & -23.969 & 0.718 & 25.058 & -0.003 & 0 & 0.018 \\
\hline Min $t Z$ & 107 & 7.322 & -26.88 & 0.492 & 27.864 & -0.003 & 0 & -0.019 \\
\hline
\end{tabular}

\section{CONCLUSIONS}

This project concludes with planning, design and analysis of a fly over.

1. Based on study area flyover construction is best and economically low cost which is essential at National Highway 216A which is always busy with traffic moment. Located at Morumpudi junction in Rajahmundry, Andhra Pradesh, India.

2.The maximum flow of traffic is along National Highway 216A which includes transportation of agricultural goods and industrial goods, so path chosen for the execution of flyover is along at National Highway 216A.

3. Construction of this structure at that junction results in the traffic control and enhances safe driving.

4. The structure is designed basing codes IRC class AA loading, IRC 6-2016 for designing.

5. The calculated Vehicle moving capacity at Morampudi Junction is $9.8 \times 10^{3} \mathrm{KN} / \mathrm{m}^{2}$.

6.It has obtained that maximum load capacity of the flyover is $98 \times 10^{3} \mathrm{KN}$.

7.It has been observed that the maximum shear force is $381.051 \mathrm{KN}$ and bending moment is $1161.445 \mathrm{KNm}$ which are in safe limit.

8. The maximum nodal displacement is occurred at node $107 ; 7.164 \mathrm{~mm}$ in $\mathrm{x},-70.178 \mathrm{~mm}$ in $\mathrm{y}$ and $0.56 \mathrm{~mm}$ in $\mathrm{z}$ directions.
9.Design structures using software's like STAAD.Pro V8i, helps in finding failed members and better section is given by the software.

10. Design structure by using software results in obtaining details of each and every member, reduces time of design work, and improved the accuracy of results.

\section{REFERENCES}

[1] IRC 21-2000 - Standard Specifications And Code Of Practice For Road Bridges Section II

[2] Rajeev Sharma (2015) 'Nonlinear Static Analysis of RC Bridge', International Journal of Civil Engineering, vol.2, Issue.5,pp.1-4.

[3] IRC 6-2000 - Standard Specifications And Code Of Practice For Road Bridges Section II

[4] Bridge Design using the STAAD.Pro/BEAVA AASHTO Code by IEG Group. Bentley System Inc.

[5] AASHTO (2003), Standard Specifications For Highway Bridges. Washington, D.C.

[6] Vikash Khali, P.R. Maiti, P.K. Singh (2012),"Analysis Of Skew Bridges Using Computational Methods" International Journal of Computational Engineering Research, VOL-2, issue no-3, pp-625-636.

[7] K.S.RAKSHIT, Design and Construction of Highway Bridges New Central Book Agency.

[8] JAYARAM,T.R. JAGADEESH AND M.A. Design of Bridge Structures Prentice Hall of India Pvt. Ltd., New Delhi.

[9] D.JOHNSON VICTOR, Essentials of Bridge Engineering Oxford and IBH Publishing Co. Pvt. Ltd.

[10] C.S. PAPACOSTAS, Fundamentals of Transportation Engineering Prentice Hall of India Pvt Ltd, New Delhi.

[11] Ajit Singh (2006), "Analysis of skew effect on slab bridges", M.Tech Dissertation IIT Roorkee.

[12] Ahmed Abdel-Mohti and Gokhan Pekcan (2013), "Assessment of seismic performance of skew on RC box gireder bridges” International Journal of Advanced structural engineering.

[13] Ansuman Kar, vikas khatri, P.R.Maiti and P.K.Singh (2012), "study on effect of skew angle in skew bridges" International journal of Engineering Research and Department, ISSN: 2278-067X, P-ISSN: 2778-800X. 